\title{
SOIL USES IN THE SUGARCANE FALLOW PERIOD TO IMPROVE CHEMICAL AND PHYSICAL PROPERTIES OF TWO LATOSOLS (OXISOLS) ${ }^{(1)}$
}

\author{
Carolina Fernandes ${ }^{(2)}$, José Eduardo Corá((3) \& Adolfo Valente Marcelo(4)
}

\begin{abstract}
SUMMARY
Sugarcane production should be integrated with crop diversification with a view to competitive and sustainable results in economic, social and environmental aspects. The purpose of this study was to assess the influence of different soil uses during the sugarcane fallow period on the chemical and physical properties of eutroferric Red Latosol - LVef (Oxisol) and Acric Latosol - LVw (Acric Oxisol),

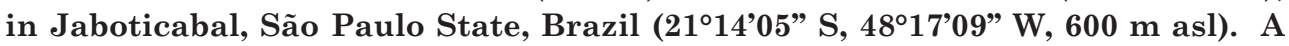
randomized block design was used with five replications and four treatments, consisting of different soil uses (crops) in the sugarcane fallow period: soybean only, soybean/fallow/soybean, soybean/millet/soybean, and soybean/sunn hemp/ soybean. After two soybean crops, the LVef chemical properties remained at intermediate to high levels; while those of the $\mathrm{LVw}$, classified as intermediate to high in the beginning, increased to high levels. Thus, the different soil uses during the sugarcane fallow period allowed the maintenance of LVef fertility levels and the improvement of those of the LVw. Two soybean crops increased macroporosity in the 0.0-0.1 m layer of the LVef; reduced soil aggregates in the 0.0-0.1 and 0.1-0.2 m layers of both soils, and reduced aggregate stability in these two layers of the LVw. Planting pearl millet or sunn hemp between the two soybean growing seasons promoted the formation of larger soil aggregates in the surface layer $(0.0-0.1 \mathrm{~m})$ of the $L V w$.
\end{abstract}

Index terms: soybean, millet, sunn hemp, soil management, cover crops.

(1) Supported by FAPESP as Regular Support Research (Proc $\mathrm{n}^{\circ}$ 2008/55504-5) and Pos-Doc. scholarship (Proc $\mathrm{n}^{\circ}$ 2008/55503-9). Received for publication in March 3, 2011 and approved in October 13, 2011.

(2) Assistant Professor of Soil Science Department, Sao Paulo State University - UNESP, Campus of Jaboticabal. Via de Acesso Prof. Paulo Donato Castellane, 14884-900, Jaboticabal (SP). E-mail: carol@fcav.unesp.br

(3) Associate Professor of Soil Science Department, Sao Paulo State University - UNESP, Campus of Jaboticabal. CNPq Researcher. E-mail: cora@fcav.unesp.br

(4) Ph.D. Student from Agronomy Graduate School (Crop Production) - UNESP, Campus of Jaboticabal. E-mail: adolfovalente@ yahoo.com.br 


\title{
RESUMO: USOS DO SOLO NO PERÍODO DE REFORMA DO CANAVIAL PARA MELHORIA DOS ATRIBUTOS QUÍMICOS E FÍSICOS DE DOIS LATOSSOLOS
}

\begin{abstract}
A produção de cana-de-açúcar deve ser fundamentada na diversificação de culturas, contemplando aspectos econômicos, sociais e ambientais. $O$ objetivo deste trabalho foi avaliar a influência de diferentes usos do solo, no período de reforma do canavial, nos atributos químicos e físicos de um Latossolo Vermelho eutroférrico (LVef) textura muito argilosa e um Latossolo Vermelho ácrico ( $L V w)$ textura argilosa. O experimento foi conduzido

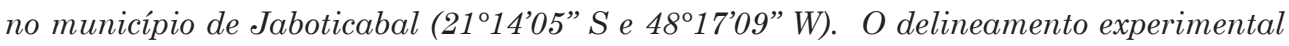
foi em blocos casualizados com cinco repetições e quatro tratamentos, caracterizados por diferentes usos do solo (cultivos) no periodo de reforma do canavial: soja, soja/pousio/ soja, soja/milheto/soja e soja/crotalária/soja. Após os dois cultivos de soja, os atributos químicos do LVef permaneceram dentro dos limites considerados como médios e altos; $e$ aqueles do LVw, antes classificados como teores médios a altos, passaram a altos. Portanto, os diferentes usos do solo, no período de reforma do canavial, promoveram a manutenção dos níveis de fertilidade do LVef e a melhoria dos níveis de fertilidade do LVw. O uso de dois cultivos de soja no período de reforma do canavial, em comparação a um cultivo de soja, proporcionou maior macroporosidade na camada de 0,0-0,1 $\mathrm{m}$ de profundidade do LVef; menor diâmetro médio ponderado dos agregados nas camadas de 0,0-0,1 e 0,1-0,2 m de profundidade dos dois solos; e menor índice de estabilidade de agregados nessas duas camadas do LVw. A utilização do milheto ou da crotalária entre os dois anos agrícolas de soja, em comparação ao pousio, favoreceu a formação de agregados maiores na camada de 0,0-0,1 $\mathrm{m}$ de profundidade do $L V w$.
\end{abstract}

Termos de indexação: soja, milheto, crotalária, manejo do solo, culturas de cobertura.

\section{INTRODUCTION}

On the world market, Brazil is the leading sugarcane producer. The national production in 2010 was estimated at 730 million tons, which was $6 \%$ higher than in 2009, harvested from an estimated area of 9 million hectares, representing an increase of $7 \%$ over 2009 (IBGE, 2011). However, to meet industrial demands, the sugarcane production must rise, new production areas have to be opened and/or yield of the active plantations increased.

Since the late $1980 \mathrm{~s}$, legume crops (peanut or soybean) have been planted between sugarcane production cycles as a crop rotation practice. Today, more than three decades after the creation of the National Ethanol Program (Programa Nacional do Álcool - Pro-álcool), the Brazilian sugar-ethanol sector faces the challenge of proving that with the implementation of technology, increases in sugarcane yield can be attained by crop diversification, education and training, and the integration of production chains; this should eventually achieve competitive and sustainable results in economic, social and environmental aspects.

Several benefits of crop rotation over monocultures are well-known e.g., improvements in physical, chemical and biological soil properties, better control of pests, diseases and weeds, and positive effects on crop yields. Crop rotation also allows the optimization of the machinery and implements on farms and production diversification.

Mascarenhas et al. (1994) assessed legume crops on a dystrophic Red Latosol, by planting velvet bean (Mucuna aterrima), sunn hemp (Crotalaria juncea) and soybean (Glycine max), between sugarcane production cycles. Their results showed a $22 \%$ increase in sugarcane yield after sunn hemp cultivation, $20 \%$ after velvet bean and $4 \%$ after soybean compared to leaving the soil fallow in the same period. Recently, Mascarenhas et al. (1994) evaluated the use of two consecutive plantings of the same legume during the sugarcane fallow period. The increase in sugarcane yield was $39 \%$ higher for sunn hemp-sunn hemp, $33 \%$ for velvet beanvelvet bean, $33 \%$ for soybean-velvet bean, $27 \%$ for velvet bean-soybean, and $26 \%$ for soybean-soybean, compared to the fallow treatment. The authors also observed an increase in sugar production of $2.4 \mathrm{t} \mathrm{ha}^{-1}$ when sugarcane was grown after sunn hemp and $2.6 \mathrm{t} \mathrm{ha}^{-1}$ after velvet bean, compared to sugarcane grown after soybean. However, an economic analysis showed a higher overall profit from the extra income of soybean sale.

The effects of legume cultivation on crops are well-known, especially $\mathrm{N}$ supply, due to the ability 
of legumes to fix atmospheric $\mathrm{N}_{2}$; this ability results in a higher plant residue degradation rate, due to a lower $\mathrm{C} / \mathrm{N}$ ratio, enhancing the nutrient releases into the soil. Grasses are known for their denser and bulkier root system, which improves the soil properties more than the pivoting root system of legume crops. Also, the plant residues of grasses have a higher $\mathrm{C} / \mathrm{N}$ ratio and a lower decomposition rate and remain on the soil surface for a longer period than legume residues.

Studies are required to determine the best soil use systems for the sugarcane fallow period, considering the economic, social and environmental aspects.

The hypothesis of this study was that the use of two soybean crops with one grass or legume cultivation in-between will improve chemical and physical soil properties during the sugarcane fallow period, increasing the potential yield of the following sugarcane cycle. Moreover, this system would include soybean grain production without decreasing the total sugarcane production cycle and increase the annual yield and longevity of the sugarcane crop.

Thus, the purpose of this study was to assess the influence of different soil uses during the sugarcane fallow period on the chemical and physical properties of eutroferric Red Latosol (Oxisol) and Acric Latosol (Acric Oxisol).

\section{MATERIALS AND METHODS}

The experiments were conducted in two areas with different soil types: a eutroferric Red Latosol (LVef) with a very clayey texture and an Acric Latosol ( $\mathrm{LVw}$ ) with a clayey texture, according to the Brazilian soil taxonomy system (Embrapa, 2006). Both areas were located in Jaboticabal County,
São Paulo State (Brazil)(approximately $21^{\circ} 14^{\prime} 05^{\prime \prime} \mathrm{S}$ latitude, $48^{\circ} 17^{\prime} 09^{\prime \prime} \mathrm{W}$ longitude, at about $600 \mathrm{~m}$ asl). According to the Köppen climate classification, the area was characterized as Aw, tropical winter dry season. The average temperature of the hottest month is $>22^{\circ} \mathrm{C}$, and of the coldest month $>18^{\circ} \mathrm{C}$. The average annual precipitation is $1,400 \mathrm{~mm}$, with an annual distribution peaking in the period from October to March and a relatively dry period from April to September. Both areas were used for sugarcane production for more than 30 years and mechanized harvesting was introduced in 1995.

Prior to the experiments, the chemical and physical properties of the two soils were assessed (Tables 1 and 2). According to the method proposed by Raij et al. (2001), the following chemical properties were determined: $\mathrm{pH}\left(\mathrm{CaCl}_{2}\right)$, organic matter contents, available $\mathrm{P}$ resin, $\mathrm{K}^{+}, \mathrm{Ca}^{2+}, \mathrm{Mg}^{2+}$, and the potential acidity $(\mathrm{H}+\mathrm{Al})$. Next, the cation exchange capacity (CEC) and base saturation percentage values were calculated. The investigated physical properties included sand, silt and clay contents, determined according to the methods of Gee \& Or (2002). The soil bulk density was measured as proposed by Grossman $\&$ Reinsch (2002). The total porosity, macroporosity and microporosity were assessed using the method proposed by Embrapa (1997), and the water aggregate stability index (ASI) and aggregate mean weight diameter (MWD) as described by Nimmo \& Perkins (2002).

The experiment was arranged in a randomized block design with five replications and four treatments consisting of different soil uses during the sugarcane fallow period. The soil uses consisted of the following crops: soybean (S), soybean/fallow/soybean (S/F/S), soybean/pearl millet/soybean $(\mathrm{S} / \mathrm{Pm} / \mathrm{S})$ and soybean/ sunn hemp/soybean (S/Sh/S). In the S treatment, one soybean (Glycine max) crop was grown from October 2009 to February 2010. In S/F/S, S/Pm/S and S/Sh/S, two soybean crops were grown in the same period

Table 1. Soil chemical properties prior to the experiment

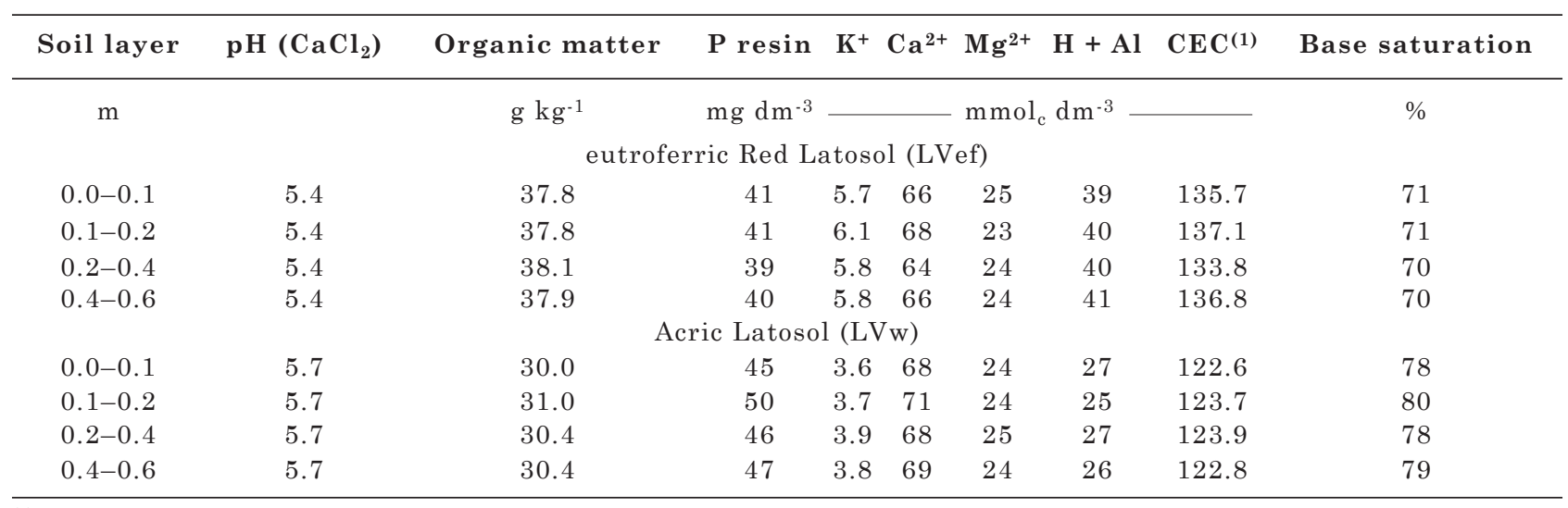

(1) CEC: Cation exchange capacity. 
Table 2. Soil physical properties prior to the experiment

\begin{tabular}{|c|c|c|c|c|c|c|c|c|c|}
\hline \multirow{2}{*}{ Soil layer } & \multicolumn{3}{|c|}{ Particle size } & \multirow{2}{*}{ Bulk density } & \multicolumn{3}{|c|}{ Soil porosity } & \multirow{2}{*}{$\mathrm{ASI}^{(1)}$} & \multirow{2}{*}{$\operatorname{MWD}^{(2)}$} \\
\hline & Sand & Silt & Clay & & Total & Macro & Micro & & \\
\hline $\mathrm{m}$ & 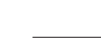 & $\mathrm{g} \mathrm{kg}^{-1}$ & 工 & $\mathrm{Mg} \mathrm{m}^{-3}$ & 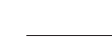 & $-\mathrm{m}^{3} \mathrm{~m}^{-3}$ & - & $\%$ & $\mathrm{~mm}$ \\
\hline \multicolumn{10}{|c|}{ eutroferric Red Latosol (LVef) } \\
\hline $0.0-0.1$ & 140 & 180 & 680 & 1.25 & 0.54 & 0.13 & 0.41 & 89 & 3.5 \\
\hline $0.1-0.2$ & 140 & 180 & 680 & 1.35 & 0.53 & 0.11 & 0.42 & 88 & 2.9 \\
\hline $0.2-0.4$ & 120 & 170 & 710 & 1.35 & 0.53 & 0.11 & 0.42 & 92 & ... \\
\hline $0.4-0.6$ & 120 & 160 & 720 & 1.27 & 0.54 & 0.13 & 0.41 & 87 & $\ldots$ \\
\hline \multicolumn{10}{|c|}{ Acric Latosol (LVw) } \\
\hline $0.0-0.1$ & 440 & 120 & 440 & 1.26 & 0.55 & 0.23 & 0.32 & 79 & 3.7 \\
\hline $0.1-0.2$ & 440 & 120 & 440 & 1.44 & 0.47 & 0.14 & 0.33 & 78 & 3.5 \\
\hline $0.2-0.4$ & 430 & 110 & 460 & 1.60 & 0.45 & 0.10 & 0.35 & 74 & $\ldots$ \\
\hline $0.4-0.6$ & 430 & 100 & 470 & 1.55 & 0.46 & 0.10 & 0.36 & 66 & $\ldots$ \\
\hline
\end{tabular}

(1) ASI: aggregate stability index. (2) MWD: mean-weight diameter.

for the growing seasons 2008/2009 and 2009/2010. Between the first and second soybean crops, from March to September 2009, the soil was left fallow (S/F/S) or pearl millet (Pennisetum americanum) (S/ $\mathrm{Pm} / \mathrm{S})$ or sunn hemp (Crotalaria. juncea) $(\mathrm{S} / \mathrm{Sh} / \mathrm{S})$ were planted.

Pearl millet and sunn hemp were selected from several options of grass and legume species for their agronomical features of sowing, maintenance and harvest, which allow the use of the same infrastructure, machinery and equipment as used for sugarcane. This avoided new investments and simplified the marketing of the produced seed.

The $270 \mathrm{~m}^{2}$ experimental plots $(18 \times 15 \mathrm{~m})$ consisted of forty $15 \mathrm{~m}$ soybean rows spaced $0.45 \mathrm{~m}$ apart. Of each plot, $45 \mathrm{~m}^{2}$ was evaluated, which included ten $10 \mathrm{~m}$ soybean rows. The plot borders consisted of 15 external rows on each side, with a $2.5 \mathrm{~m}$ space at either end of each row. Within each block, the plots were separated by $10 \mathrm{~m}$ tracks, with $3 \mathrm{~m}$ tracks between the blocks. The plot and track sizes were defined to facilitate machinery operation during the experiment.

Before beginning the experiment, the root system of the previous sugarcane cycle was removed mechanically.

In the two growing seasons (2008/2009 and 2009/2010), the soybean variety Coodetec 216 was sown in a row spacing of $0.45 \mathrm{~m}$ to obtain a plant density of 400,000 plants $\mathrm{ha}^{-1}$. Fertilization at sowing consisted of $300 \mathrm{~kg} \mathrm{ha}^{-1}$ of the NPK fertilizer 3-30-10. During the crop cycle, pest and disease control products were applied according to the specific technical recommendations for soybean.

Approximately 120 days after sowing, soybean was mechanically harvested. The final grain weight was calculated for a moisture content of $0.13 \mathrm{~kg} \mathrm{~kg}^{-1}$, and the yield values expressed in $\mathrm{kg} \mathrm{ha}^{-1}$.
After soybean harvest, the plant residues on the soil surface were evaluated by sampling three areas $\left(0.25 \mathrm{~m}^{2}\right.$ per plot), according to a procedure recommended by Stott et al. (1990). After determining the sample dry mass, the residues were analyzed for concentrations of organic carbon (Tedesco et al., 1995), N, P, K, Ca, Mg and S (Bataglia et al., 1983). Based on the results of the dry mass produced and the nutrient concentrations, the quantity of accumulated nutrients and the $\mathrm{C} / \mathrm{N}$ ratio were calculated.

Pearl millet and sunn hemp were sown with a no-tillage drill in rows spaced $0.45 \mathrm{~m}$ apart, and no fertilizer was applied. A plant density of $3,000,000$ plants ha ${ }^{-1}$ was estimated for pearl millet and of 555,500 plants ha ${ }^{-1}$ for sunn hemp. Using a mechanical harvester, pearl millet and sunn hemp crops were harvested 144 and 166 days after sowing, respectively. Subsequently, the final seed weight was calculated considering a moisture content of $0.13 \mathrm{~kg} \mathrm{~kg}^{-1}$, and the yield values were obtained. After harvest, the plant residues on the soil surface were evaluated as described above for soybean.

The plots left fallow were periodically handweeded to keep the soil surface free of spontaneous vegetation for comparison with the treatments in which pearl millet or sunn hemp were planted between the two soybean crops.

At the end of the experiment, the chemical and physical properties of LVef and LVw were assessed after soybean harvest in the 2009/2010 growing season as previously described.

To determine the soil chemical properties, disturbed soil samples were collected with a soil auger (layers $0.0-0.1,0.1-0.2,0.2-0.4$ and $0.4-0.6 \mathrm{~m}$ ). For each soil layer, a composite sample of three single samples was mixed. 
Undisturbed samples were also collected at three sites per plot to determine the aggregate stability index (ASI) and mean weight diameter (MWD) of aggregates. To determine ASI in the four sampled layers, aggregate diameters between 1.0 and $2.0 \mathrm{~mm}$ were considered. To determine MWD in the layers $0.0-0.1$ and $0.1-0.2 \mathrm{~m}$, aggregates with diameters between 4.0 and $6.3 \mathrm{~mm}$ were used and a set of sieves (mesh size 4.0, 2.0, 1.0, 0.5, 0.25 and $0.125 \mathrm{~mm}$ ).

To determine the remaining physical properties, three undisturbed soil samples were collected in volumetric rings $(5 \times 5 \mathrm{~cm})$ at each of the four depths, avoiding closeness to the machinery and implement track.

Analysis of variance was applied to all variables in a randomized block design with five replications and four treatments (soil uses in the sugarcane fallow period). The degrees of freedom for the treatments were converted into three mutually orthogonal contrasts, and the significance of each contrast was determined by the F-test at $1 \%$.

The contrast S v SS compared soybean for one (S) and two (SS) growing seasons. The contrast F v PmSh compared the soil maintenance on fallow (F) ground and with the cultivation of pearl millet $(\mathrm{Pm})$ or sunn hemp (Sh) between the two soybean crops. The contrast $\mathrm{Pm} v \mathrm{Sh}$ compared the cultivation of pearl millet (Pm) and sunn hemp (Sh) between the two soybean crops.

\section{RESULTS AND DISCUSSION}

Pearl millet and sunn hemp planted between the soybean cycles developed adequately on LVef and on $\mathrm{LVw}$. The grain yield was determined visually before the harvest and was within the expected range, but the effective grain yield was low for both areas (Table 3), which was attributed to bird attack several days before the harvest. The proper growth of pearl millet and sunn hemp was evidenced by the residue dry matter amounts (Table 3). Our results agreed with those found in the literature (Perin et al., 2004; Silva et al., 2006; Suzuki \& Alves, 2006; Almeida et al., 2008; Suzuki et al., 2008).
After pearl millet cultivation, the plant residues on the soil surface accumulated high levels of N, Ca and $\mathrm{S}$, but after sunn hemp cultivation, high levels of N, K and Ca were found (Table 4). Perin et al. (2004) observed K accumulation in pearl millet and $\mathrm{N}$ and $\mathrm{K}$ in sunn hemp 68 days after sowing. Cazetta et al. (2005) determined the following quantities of elements (in $\mathrm{kg} \mathrm{ha}^{-1}$ ) 60 days after emergence,: $265 \mathrm{~N}, 32 \mathrm{P}, 156 \mathrm{~K}, 63 \mathrm{Ca}, 37 \mathrm{Mg}$ and $17 \mathrm{~S}$ for pearl millet and $137 \mathrm{~N}, 11 \mathrm{P}, 62 \mathrm{~K}, 45 \mathrm{Ca}, 21 \mathrm{Mg}$ and $6 \mathrm{~S}$ for sunn hemp. These amounts are higher than in our experiments (Table 4), where the nutrient levels were determined in the plant residues after harvesting pearl millet and sunn hemp seeds 144 and 166 days after sowing, respectively. This indicates the occurrence of nutrient redistribution from the plant mass into the seeds, reducing nutrient accumulation in the crop residues. Braz et al. (2004) observed that the maximum nutrient accumulation in pearl millet occurred between 52 and 55 days after germination, when nutrient redistribution into the seeds began, resulting in decreased accumulation in pearl millet leaves.

The $\mathrm{C} / \mathrm{N}$ ratios of the plant residues on the soil surface after pearl millet and sunn hemp harvest were similar for LVef and LVw (Table 4). After the harvest of pearl millet and sunn hemp, the plant residues present on the soil surface consisted of a mixture of these two crops with older soybean residues (2008/2009). Thus, partially degraded soybean residues were mixed with the fresh-cut pearl millet and sunn hemp residues and influenced the observed the $\mathrm{C} / \mathrm{N}$ ratio of the residues.

In the 2009/2010 growing season, the soybean yields on LVef were statistically similar when one or two soybean crops were used (contrast S v SS) (Table 5). However, when the soil uses associated with two soybean crops were compared, soybean yield was higher in the area left fallow than in the areas with pearl millet or sunn hemp crops between the two soybean crops (contrast F v PmSh). Because pearl millet and sunn hemp were grown for seed yield, it was inferred that these crops absorbed a determined amount of soil nutrients, reducing the availability of these nutrients for the following soybean crop cycle. In the area

Table 3. Grain yield and residue dry matter after pearl millet and sunn hemp harvest

\begin{tabular}{ccccc}
\hline & \multicolumn{2}{c}{ eutroferric Red Latosol (LVef) } & \multicolumn{2}{c}{ Acric Latosol (LVw) } \\
\cline { 2 - 3 } & Grain yield & Dry matter & Grain yield & Dry matter \\
\cline { 2 - 5 } Pearl millet & 559 & 7,216 & $\mathrm{~kg}^{-1}$ & 5,826 \\
Sunn hemp & 62 & 8,204 & 60 & 9,276 \\
\hline
\end{tabular}


Table 4. Residue nutrient accumulation and $\mathrm{C} / \mathrm{N}$ ratio after pearl millet and sunn hemp harvest

\begin{tabular}{|c|c|c|c|c|c|c|c|c|c|c|c|c|c|c|}
\hline & \multicolumn{7}{|c|}{ eutroferric Red Latosol (LVef) } & \multicolumn{7}{|c|}{ Acric Latosol (LVw) } \\
\hline & $\mathbf{N}$ & $\mathbf{P}$ & $\mathbf{K}$ & $\mathbf{C a}$ & Mg & $\mathbf{S}$ & $\mathrm{C} / \mathrm{N}$ & $\mathbf{N}$ & $\mathbf{P}$ & $\mathbf{K}$ & $\mathbf{C a}$ & Mg & $\mathbf{S}$ & $\mathrm{C} / \mathrm{N}$ \\
\hline & \multicolumn{6}{|c|}{$-\mathrm{kg} \mathrm{ha}^{-1}$} & & \multicolumn{6}{|c|}{ - $\mathrm{kg} \mathrm{ha}^{-1}$} & \\
\hline Pearl millet & 50.1 & 8.6 & 12.7 & 15.8 & 7.8 & 23.7 & 51.6 & 55.9 & 5.4 & 11.3 & 16.4 & 8.5 & 13.9 & 45.8 \\
\hline Sunn hemp & 55.4 & 4.7 & 24.1 & 23.3 & 7.4 & 6.5 & 48.4 & 52.9 & 5.5 & 27.3 & 18.8 & 6.2 & 5.3 & 47.9 \\
\hline
\end{tabular}

left fallow, the nutrients that became available by the decomposition of plant residues from the first soybean crop (2008/2009 growing season) remained in the soil and were taken up by the following soybean cycle (2009/2010 growing season). Furthermore, in this experiment, the soil surface exposure of the area left fallow may promote the degradation of physical, chemical and biological soil properties over time. Crop cultivation maintains the soil covered and recycles nutrients through biomass, supplying part of the nutrients of the following crop by residue decomposition, which is economically and environmentally reasonable (Almeida et al., 2008). Moreover, harvesting of pearl millet and sunn hemp for seed production between the two soybean crops increased the annual economical return. In the comparison of the effects of pearl millet and sunn hemp (contrast Pm v Sh), it was noted that soybean yield (Table 5) was higher when this crop was grown after sunn hemp than after pearl millet. Marcelo et al. (2009) evaluated different sequences of summer crops and seven winter crops in a eutroferric Red Latosol and reported a higher soybean yield $\left(3,206 \mathrm{~kg} \mathrm{ha}^{-1}\right)$ after sunn hemp cultivation.
Soybean yields on LVw (Table 5) were statistically similar when grown after removing the sugarcane root system (S) or after soybean (growing season 2008/2009) followed by a fallow period (F), pearl millet $(\mathrm{Pm})$ or sunn hemp (Sh). Guimarães et al. (2003) assessed the effects of using cover crops or a fallow period on subsequent soybean and found that soybean yields on a dystrophic Red Latosol were similar in both cases. Almeida et al. (2008) also observed that pearl millet or sunn hemp versus a fallow period did not influence soybean yield; in contrast, Marcelo et al. (2009) reported a higher soybean yield after sunn hemp.

The different soil uses provided the same amount of plant residue dry matter on the soil surface after soybean harvest (Table 5), as also noted by Guimarães et al. (2003) for a dystrophic Red Latosol.

The accumulated nutrient amounts and $\mathrm{C} / \mathrm{N}$ ratios in the plant residues after soybean harvest on LVef were not influenced by the different soil uses (Table 6). This was also observed for the crops grown on $\mathrm{LVw}$, except for $\mathrm{Ca}$, for which residue

Table 5. Soybean yield and residue dry matter amount after the grain harvest in March 2010 and significance of the contrasts

\begin{tabular}{|c|c|c|c|c|}
\hline \multirow{2}{*}{ Soil use ${ }^{(1)}$} & \multicolumn{2}{|c|}{ eutroferric Red Latosol (LVef) } & \multicolumn{2}{|c|}{ Acric Latosol (LVw) } \\
\hline & Grain yield & Dry matter & Grain yield & Dry matter \\
\hline & & $\mathrm{kg}$ & & \\
\hline $\mathrm{S}$ & $3,759.1$ & $6,240.7$ & $3,825.2$ & $5,594.6$ \\
\hline $\mathrm{S} / \mathrm{F} / \mathrm{S}$ & $3,892.8$ & $6,486.0$ & $3,779.4$ & $6,040.1$ \\
\hline $\mathrm{S} / \mathrm{Pm} / \mathrm{S}$ & $3,558.7$ & $6,588.0$ & $3,889.7$ & $5,936.5$ \\
\hline $\mathrm{S} / \mathrm{Sh} / \mathrm{S}$ & $3,773.3$ & $6,290.7$ & $3,746.4$ & $5,507.2$ \\
\hline Contrast ${ }^{(2)}$ & & & & \\
\hline$F$-test $(\mathrm{S} \vee \mathrm{SS})$ & NS & NS & NS & NS \\
\hline$F$-test $(\mathrm{F} \vee \mathrm{PmSh})$ & $* *$ & NS & NS & NS \\
\hline$F$-test $(\mathrm{Pm} v \mathrm{Sh})$ & $* *$ & NS & NS & NS \\
\hline $\mathrm{CV}(\%)$ & 3 & 21 & 4 & 25 \\
\hline
\end{tabular}

(1) S: soybean; S/F/S: soybean/fallow/soybean; S/Pm/S: soybean/pearl millet/soybean; S/Sh/S: soybean/sunn hemp/soybean. (2) $\mathrm{S}$ v SS: mean contrast between one (S) and two (SS) soybean crops; F v PmSh: mean contrast between fallow (F) and crops (PmSh) in the interval between two soybean crops; Pm v Sh: mean contrast between pearl millet (Pm) and sunn hemp (Sh) between two soybean crops. NS: not significant at $5 \% ;{ }^{* *}$ : significant at $1 \%$. 
Table 6. Residue nutrient accumulation and $\mathrm{C} / \mathrm{N}$ ratio after the grain harvest in March 2010 and significance of the contrasts

\begin{tabular}{|c|c|c|c|c|c|c|c|c|c|c|c|c|c|c|}
\hline \multirow{2}{*}{ Soil use ${ }^{(1)}$} & \multicolumn{7}{|c|}{ eutroferric Red Latosol (LVef) } & \multicolumn{7}{|c|}{ Acric Latosol (LVw) } \\
\hline & $\mathbf{N}$ & $\mathbf{P}$ & $\mathbf{K}$ & $\mathbf{C a}$ & $\mathrm{Mg}$ & $\mathrm{S}$ & $\mathrm{C} / \mathrm{N}$ & $\mathbf{N}$ & $\mathbf{P}$ & $\mathbf{K}$ & $\mathbf{C a}$ & Mg & $\mathbf{S}$ & $\mathrm{C} / \mathrm{N}$ \\
\hline & \multicolumn{6}{|c|}{$-\mathrm{kg} \mathrm{ha}^{-1}$} & & \multicolumn{6}{|c|}{$\mathrm{kg} \mathrm{ha}^{-1}$} & \\
\hline $\mathrm{S}$ & 46.2 & 4.1 & 28.0 & 65.6 & 14.8 & 5.8 & 53.7 & 44.7 & 3.0 & 10.4 & 33.3 & 9.1 & 2.9 & 47.4 \\
\hline $\mathrm{S} / \mathrm{F} / \mathrm{S}$ & 53.1 & 2.8 & 17.8 & 50.7 & 15.3 & 5.1 & 49.4 & 45.4 & 3.7 & 5.4 & 42.3 & 13.3 & 3.5 & 53.9 \\
\hline $\mathrm{S} / \mathrm{Pm} / \mathrm{S}$ & 62.8 & 3.2 & 24.9 & 57.9 & 16.2 & 4.2 & 42.3 & 56.8 & 3.4 & 8.6 & 45.4 & 12.4 & 4.0 & 45.3 \\
\hline $\mathrm{S} / \mathrm{Sh} / \mathrm{S}$ & 45.4 & 2.5 & 25.7 & 45.5 & 14.8 & 3.7 & 55.1 & 41.9 & 3.3 & 10.3 & 33.4 & 11.3 & 2.4 & 53.5 \\
\hline \multicolumn{15}{|l|}{ Contrast ${ }^{(2)}$} \\
\hline$F$-test (S v SS) & NS & NS & NS & NS & NS & NS & NS & NS & NS & NS & NS & NS & NS & NS \\
\hline$F$-test (F v PmSh) & NS & NS & NS & NS & NS & NS & NS & NS & NS & NS & NS & NS & NS & NS \\
\hline$F$-test (Pm v Sh) & NS & NS & NS & NS & NS & NS & NS & NS & NS & NS & $* *$ & NS & NS & NS \\
\hline $\mathrm{CV}(\%)$ & 18 & 27 & 29 & 22 & 17 & 25 & 20 & 39 & 42 & 50 & 15 & 24 & 48 & 19 \\
\hline
\end{tabular}

(1) S: soybean; S/F/S: soybean/fallow/soybean; S/Pm/S: soybean/pearl millet/soybean; S/Sh/S: soybean/sunn hemp/soybean. (2) S v SS: mean contrast between one (S) and two (SS) soybean crops; F v PmSh: mean contrast between fallow (F) and crops (PmSh) in the interval between two soybean crops; Pm v Sh: mean contrast between pearl millet (Pm) and sunn hemp (Sh) between two soybean crops. NS: not significant at $5 \%$.

concentrations were higher when soybean was grown after pearl millet instead of sunn hemp.

The different soil uses did not influence the chemical properties of LVef in the layers $0.0-0.1$, $0.1-0.2,0.2-0.4$, and $0.4-0.6 \mathrm{~m}$ (Table 7). The values were within the intermediate and high limits suggested by Raij et al. (1997). Thus, adopting one or two soybean crops and using pearl millet or sunn hemp or leaving the soil fallow between cultivations maintained the chemical properties of LVef because the chemical levels were also classified as intermediate and high before the experiment (Table 1) (Raij et al., 1997). Guimarães et al. (2003) similarly observed that the chemical properties of a dystrophic Red Latosol determined after a soybean harvest in the layers $0.0-0.1,0.1-0.2$ and $0.2-0.4 \mathrm{~m}$ were not influenced by cover crops or fallow period before soybean crop.

The use of two soybean crops on $\mathrm{LVw}$ increased $\mathrm{P}$ resin in the $0.0-0.1$ and $0.1-0.2 \mathrm{~m}$ layers, $\mathrm{K}^{+}$in the 0.2-0.4 and 0.4-0.6 $\mathrm{m}$ layers and $\mathrm{Ca}^{2+}$ in the $0.1-0.2$ and $0.4-0.6 \mathrm{~m}$ layers, compared to the use of only one soybean crop (contrast S v SS) (Table 7). Similarly, with two soybean crops, the CEC increased in the 0.1-0.2 $\mathrm{m}$, and base saturation in the $0.4-0.6 \mathrm{~m}$ layer. Lower contents of $\mathrm{Mg}^{2+}$ were found in the $0.0-0.1 \mathrm{~m}$ layer, and the $\mathrm{H}+\mathrm{Al}$ was lower in the $0.2-0.4 \mathrm{~m}$ layer. The greater number of cultivations using different types of crops allowed the exploration of different soil depths and provided a varied range of plant residues, which most likely contributed to the biological diversification of the soil and enabled nutrient recycling and distribution. After the cultivation of two soybean crops, the chemical properties of the $\mathrm{LVw}$ were in a range considered high by Raij et al. (1997), and were higher than the intermediate to high levels determined before the experiment (Table 1) (Raij et al., 1997). Consequently, the sequence of two soybean crops promoted an improvement of the LVw fertility levels, regardless of the soil use between crops.

The difference observed between the effects of the soil uses on the chemical properties of LVef and LVw was explained by the differences in the clay and organic matter contents of these soils. In the LVef, with a very clayey texture, higher contents of clay and organic matter were observed than in $\mathrm{LVw}$, which had a clayey texture (Tables 1 and 2) and consequently a higher CEC (Table 1). Thus, to assess a response from LVef to different soil uses, greater amounts of nutrients must be supplied than for $\mathrm{LVw}$, due to the higher clay and organic matter content of LVef.

Pearl millet or sunn hemp cultivation between the two soybean crops did not influence the chemical properties of LVef and LVw (Table 7). Moreti et al. (2007) also noted that when sunn hemp and pearl millet were used as cover crop, they did not influence the chemical properties of a dystrophic Red Latosol with a clayey texture.

In the 0.0-0.1 m layer of LVef, a higher macroporosity volume was observed after two soybean crops (SS) than after one (S) (Table 8). The use of a greater number of cycles of different crops with different root systems most likely resulted in the formation of biopores, increasing the soil macroporosity volume. According to Stone \& Silveira (2001), the inclusion of species with distinct root systems and different 
Table 7. Soil chemical properties at different soil layer at the end of the experiment, and significance of the contrasts

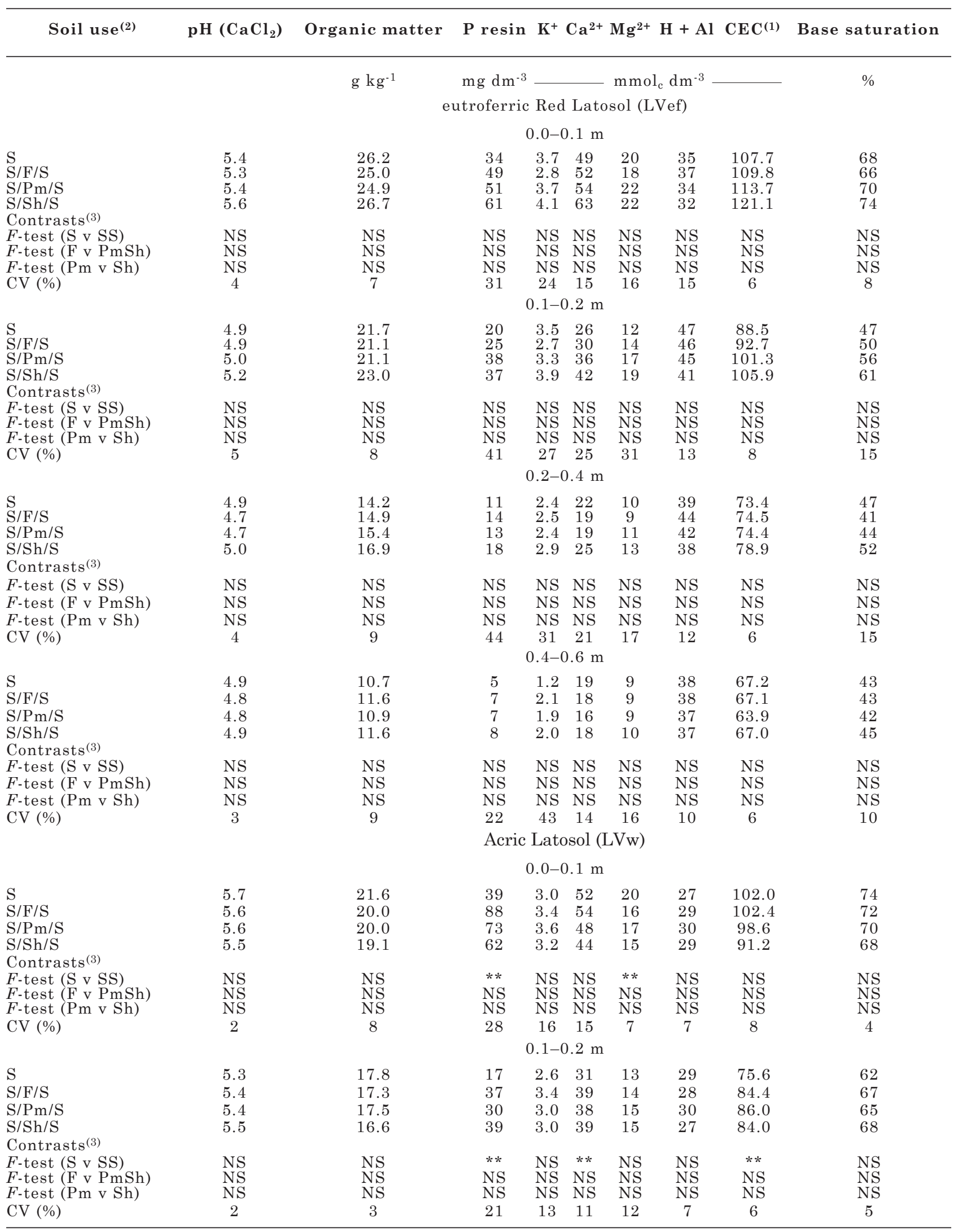


Table 7. Continue

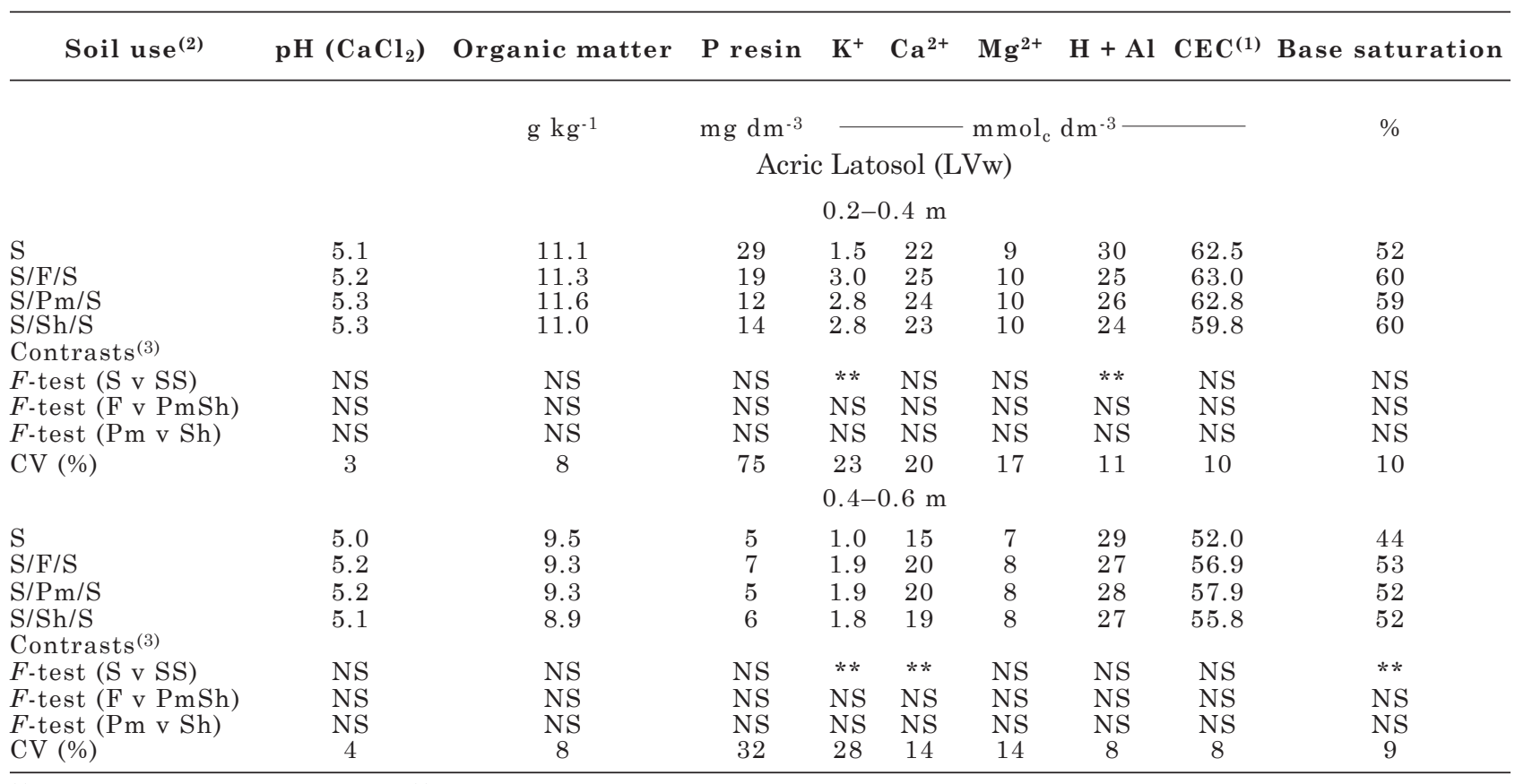

(1) CEC: Cation exchange capacity. ${ }^{(2)}$ S: soybean; S/F/S: soybean/fallow/soybean; S/Pm/S: soybean/pearl millet/soybean; S/Sh/S: soybean/sunn hemp/soybean. (3) S v SS: mean contrast between one (S) and two (SS) soybean crops; F v PmSh: mean contrast between fallow (F) and crops (PmSh) in the interval between two soybean crops; Pm v Sh: mean contrast between pearl millet (Pm) and sunn hemp (Sh) between two soybean crops. ${ }^{\text {NS: }}$ not significant at $5 \%$; ${ }^{* *}$ : significant at $1 \%$.

dry matter contributions could alter soil physical proprieties, but the intensity of these alterations depends on the cultivation period, the number of crops per year and the crop species.

The MWD of aggregates in the LVef and LVw was lower after two soybean (SS) than after only one soybean crop (S) in the 0.0-0.1 and 0.1-0.2 m layers (Table 8). The use of a higher number of crops resulted in more intense soil tillage, which compromised the formation of larger diameter aggregates. In a comparison of the fallow period with two soybean crops (contrast F v PmSh) on LVw, it was noted that the use of pearl millet or sunn hemp promoted the formation of larger diameter aggregates in the $0.0-0.1 \mathrm{~m}$ layer. The role of soil organic matter in the formation of aggregates is well-known, but in our experiment, no differences were observed in the organic matter contents in

Table 8. Soil physical properties at different soil layer at the end of the experiment, and significance of the contrasts

\begin{tabular}{|c|c|c|c|c|c|c|c|c|c|c|c|c|}
\hline \multirow{4}{*}{ Soil use ${ }^{(3)}$} & \multicolumn{6}{|c|}{ eutroferric Red Latosol (LVef) } & \multicolumn{6}{|c|}{ Acric Latossol (LVw) } \\
\hline & \multirow[b]{2}{*}{ Bulk density } & \multicolumn{3}{|c|}{ Soil porosity } & \multirow{2}{*}{\multicolumn{3}{|c|}{ MWD $^{(1)} \mathrm{ASI}^{(2)}$ Bulk density }} & \multicolumn{3}{|c|}{ Soil porosity } & \multirow{2}{*}{\multicolumn{2}{|c|}{$\operatorname{MWD}^{(1)} \mathrm{ASI}^{(2}$}} \\
\hline & & \multicolumn{3}{|c|}{$\overline{\text { Total Macro Micro }}$} & & & & \multicolumn{3}{|c|}{$\overline{\text { Total Macro Micro }}$} & & \\
\hline & $\mathrm{Mg} \mathrm{m}^{-3}$ & $\longrightarrow$ & $\mathrm{m}^{3} \mathrm{~m}^{-3}$ & 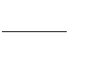 & $\mathrm{mm}$ & $\%$ & $\mathrm{Mg} \mathrm{m}^{-3}$ & 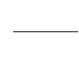 & $\mathrm{m}^{3} \mathrm{~m}^{-}$ & - & $\mathrm{mm}$ & $\%$ \\
\hline & & & & & & $0.0-0.1$ & & & & & & \\
\hline $\mathrm{S}$ & 1.4 & 0.47 & 0.05 & 0.42 & 3.6 & 92 & 1.5 & 0.39 & 0.09 & 0.30 & 4.7 & 82 \\
\hline $\mathrm{S} / \mathrm{F} / \mathrm{S}$ & 1.3 & 0.48 & 0.10 & 0.38 & 2.7 & 93 & 1.6 & 0.36 & 0.07 & 0.29 & 1.9 & 77 \\
\hline $\mathrm{S} / \mathrm{Pm} / \mathrm{S}$ & 1.4 & 0.48 & 0.09 & 0.39 & 2.9 & 93 & 1.6 & 0.36 & 0.06 & 0.30 & 2.9 & 76 \\
\hline $\mathrm{S} / \mathrm{Sh} / \mathrm{S}$ & 1.3 & 0.46 & 0.11 & 0.35 & 3.2 & 93 & 1.6 & 0.36 & 0.05 & 0.31 & 2.4 & 76 \\
\hline Contrasts $^{(4)}$ & & & & & & & & & & & & \\
\hline$F$-test $(\mathrm{S} \vee \mathrm{SS})$ & NS & NS & $* *$ & NS & $* *$ & NS & NS & NS & NS & NS & $* *$ & $* *$ \\
\hline$F$-test ( $\mathrm{F}$ v PmSh) & NS & NS & NS & NS & NS & NS & NS & NS & NS & NS & $* *$ & NS \\
\hline$F$-test (Pm v Sh) & NS & NS & NS & $\mathrm{NS}$ & NS & NS & NS & NS & NS & NS & NS & NS \\
\hline $\mathrm{CV}(\%)$ & 3 & 4 & 24 & 9 & 13 & 1 & 3 & 8 & 32 & 10 & 10 & 4 \\
\hline
\end{tabular}


Table 8. Continue

\begin{tabular}{|c|c|c|c|c|c|c|c|c|c|c|c|c|}
\hline \multirow{4}{*}{ Soil use ${ }^{(3)}$} & \multicolumn{6}{|c|}{ eutroferric Red Latosol (LVef) } & \multicolumn{6}{|c|}{ Acric Latossol (LVw) } \\
\hline & \multirow{2}{*}{ Bulk density } & \multicolumn{3}{|c|}{ Soil porosity } & \multirow{2}{*}{\multicolumn{3}{|c|}{$\operatorname{MWD}^{(1)} \mathrm{ASI}^{(2)}$ Bulk density }} & \multicolumn{3}{|c|}{ Soil porosity } & \multirow{2}{*}{\multicolumn{2}{|c|}{$\operatorname{MWD}^{(1)} \mathrm{ASI}^{(2}$}} \\
\hline & & \multicolumn{3}{|c|}{ Total Macro Micro } & & & & \multicolumn{3}{|c|}{$\overline{\text { Total Macro Micro }}$} & & \\
\hline & $\mathrm{Mg} \mathrm{m}^{-3}$ & $\longrightarrow$ & $\mathrm{m}^{3} \mathrm{~m}^{-3}$ & - & $\mathrm{mm}$ & $\%$ & $\mathrm{Mg} \mathrm{m}^{-3}$ & - & \multicolumn{2}{|c|}{$\mathrm{m}^{3} \mathrm{~m}^{-3}$} & $\mathrm{~mm}$ & $\%$ \\
\hline & \multicolumn{12}{|c|}{$0.1-0.2 \mathrm{~m}$} \\
\hline $\mathrm{S}$ & 1.4 & 0.45 & 0.06 & 0.39 & 3.2 & 91 & 1.6 & 0.35 & 0.07 & 0.28 & 3.6 & 78 \\
\hline $\mathrm{S} / \mathrm{F} / \mathrm{S}$ & 1.4 & 0.46 & 0.08 & 0.38 & 2.4 & 93 & 1.7 & 0.34 & 0.06 & 0.28 & 2.4 & 73 \\
\hline $\mathrm{S} / \mathrm{Pm} / \mathrm{S}$ & 1.4 & 0.45 & 0.08 & 0.37 & 2.5 & 92 & 1.7 & 0.34 & 0.06 & 0.28 & 2.7 & 74 \\
\hline $\mathrm{S} / \mathrm{Sh} / \mathrm{S}$ & 1.4 & 0.46 & 0.08 & 0.38 & 2.6 & 92 & 1.7 & 0.33 & 0.05 & 0.28 & 2.5 & 74 \\
\hline $\begin{array}{l}\text { Contrasts } \\
F \text {-test }(\mathrm{S} \text { v SS) }\end{array}$ & NS & NS & NS & NS & $* *$ & NS & NS & NS & NS & NS & $* *$ & $* *$ \\
\hline$F$-test (F v PmSh) & $\mathrm{NS}$ & NS & $\mathrm{NS}$ & $\mathrm{NS}$ & NS & NS & NS & NS & $\mathrm{NS}$ & NS & NS & $\mathrm{NS}$ \\
\hline$F$-test $(\mathrm{Pm} \vee \mathrm{Sh})$ & NS & NS & NS & NS & NS & NS & NS & NS & NS & NS & NS & $\mathrm{NS}$ \\
\hline \multirow[t]{2}{*}{ CV (\%) } & 2 & 3 & 25 & 5 & 16 & 1 & 2 & 9 & 24 & 11 & 12 & 3 \\
\hline & \multicolumn{12}{|c|}{$0.2-0.4 \mathrm{~m}$} \\
\hline $\mathrm{S}$ & 1.4 & 0.45 & 0.06 & 0.39 & & 88 & 1.7 & 0.36 & 0.07 & 0.29 & & 68 \\
\hline $\mathrm{S} / \mathrm{F} / \mathrm{S}$ & 1.5 & 0.45 & 0.07 & 0.38 & & 87 & 1.7 & 0.35 & 0.07 & 0.28 & & 67 \\
\hline $\mathrm{S} / \mathrm{Pm} / \mathrm{S}$ & 1.5 & 0.45 & 0.07 & 0.38 & & 88 & 1.7 & 0.35 & 0.06 & 0.29 & & 67 \\
\hline $\mathrm{S} / \mathrm{Sh} / \mathrm{S}$ & 1.4 & 0.47 & 0.07 & 0.40 & & 88 & 1.7 & 0.34 & 0.06 & 0.28 & & 65 \\
\hline \multicolumn{13}{|l|}{ Contrasts $^{(4)}$} \\
\hline$F$-test $(\mathrm{S} \vee \mathrm{SS})$ & NS & NS & NS & NS & & NS & NS & NS & NS & NS & & NS \\
\hline$F$-test $(\mathrm{F}$ v $\mathrm{PmSh})$ & NS & NS & NS & NS & & $\mathrm{NS}$ & NS & NS & NS & NS & & $\mathrm{NS}$ \\
\hline$F$-test $(\mathrm{Pm} \vee \mathrm{Sh})$ & NS & $\mathrm{NS}$ & NS & NS & & $\mathrm{NS}$ & NS & NS & NS & NS & & $\mathrm{NS}$ \\
\hline \multirow[t]{2}{*}{ CV (\%) } & 1 & 3 & 25 & 3 & & 4 & 2 & 10 & 17 & 10 & & 4 \\
\hline & \multicolumn{12}{|c|}{$0.4-0.6 \mathrm{~m}$} \\
\hline $\mathrm{S}$ & 1.4 & 0.48 & 0.07 & 0.41 & & 88 & 1.6 & 0.39 & 0.09 & 0.30 & & 69 \\
\hline $\mathrm{S} / \mathrm{F} / \mathrm{S}$ & 1.5 & 0.45 & 0.07 & 0.38 & & 83 & 1.6 & 0.38 & 0.09 & 0.29 & & 67 \\
\hline $\mathrm{S} / \mathrm{Pm} / \mathrm{S}$ & 1.4 & 0.45 & 0.07 & 0.38 & & 85 & 1.6 & 0.36 & 0.07 & 0.29 & & 67 \\
\hline $\mathrm{S} / \mathrm{Sh} / \mathrm{S}$ & 1.4 & 0.47 & 0.08 & 0.39 & & 84 & 1.6 & 0.37 & 0.08 & 0.29 & & 67 \\
\hline Contrasts $^{(4)}$ & & & & & & & & & & & & \\
\hline$F$-test $(\mathrm{S}$ v SS) & NS & NS & NS & NS & & NS & NS & NS & NS & NS & & $\mathrm{NS}$ \\
\hline$F$-test ( $\mathrm{F} \vee \mathrm{PmSh})$ & NS & NS & NS & NS & & NS & NS & NS & NS & NS & & NS \\
\hline$F$-test (Pm v Sh) & NS & NS & NS & NS & & NS & NS & NS & NS & NS & & NS \\
\hline CV $(\%)$ & 2 & 4 & 15 & 5 & & 4 & 3 & 7 & 21 & 7 & & 4 \\
\hline
\end{tabular}

(1) ASI: aggregate stability index. (2) MWD: mean-weight diameter. ${ }^{(3)}$ S: soybean; S/F/S: soybean/fallow/soybean; S/Pm/S: soybean/ pearl millet/soybean; S/Sh/S: soybean/sunn hemp/soybean. ${ }^{(4)} \mathrm{S} v \mathrm{SS}$ : mean contrast between one (S) and two (SS) soybean crops; F v PmSh: mean contrast between fallow (F) and crops (PmSh) in the interval between two soybean crops; Pm v Sh: mean contrast between pearl millet (Pm) and sunn hemp (Sh) between two soybean crops. NS: not significant at $5 \%$; ${ }^{* *}$ : significant at $1 \%$.

the assessed soil layers (Table 7), as also stated by Campos et al. (1999). Nevertheless, the authors emphasized that the introduction of cover crops improves the soil structural stability due to the quantity of dry matter produced. In this study, high dry matter amounts in the pearl millet and sunn hemp residues were also observed on $\mathrm{LVw}$ (Table 3). Under these conditions, it can safely be concluded that other factors affected organic matter more directly than aggregate stability. These results reinforce the importance of soil cover with for soil aggregation, to prevent the direct action of rain, decrease the thermal amplitude and keep the soil moist, favoring the development of the root system and microbial activity and consequently producing a beneficial environment for soil aggregation (Campos et al., 1999).

In LVw, the ASI in the 0.0-0.1 and 0.1-0.2 m layers was lower after two soybean crops (SS) than after one (S) (Table 8), confirming that the increased soil tillage did not allow the formation of stable soil aggregates. No changes were observed in the ASI on LVef (Table 8). Due to the higher clay levels, the LVef has a higher ASI than LVw (Table 2) and is more resistant to interferences related to soil uses.

The different soil uses in the sugarcane fallow period promoted changes in the chemical and physical soil properties that modified the soil dynamics for the following sugarcane cycle.

\section{CONCLUSIONS}

1. The different soil uses assessed in the sugarcane fallow period maintained the fertility levels in the eutroferric Red Latosol (Oxisol) and improved those of the Acric Latosol (Acric Oxisol). 
2. The use of a greater number of crops did not allow the formation of larger diameter soil aggregates in either soil.

3. The use of two soybean crops instead of one during the sugarcane fallow period resulted in a high macroporosity in the in the $0.0-0.1 \mathrm{~m}$ layer in the eutroferric Red Latosol.

4. Planting pearl millet or sunn hemp between the two soybean crops instead of leaving the soil fallow promoted the formation of larger soil aggregates in the $0.0-0.1 \mathrm{~m}$ layer in the Acric Latosol.

\section{LITERATURE CITED}

ALMEIDA, V.P.; ALVES, M.C.; SILVA, E.C. \& OLIVEIRA, S.A. Rotação de culturas e propriedades físicas e químicas em Latossolo Vermelho de Cerrado sob preparo convencional e semeadura direta em adoção. R. Bras. Ci. Solo, 32:12271237, 2008.

BATAGLIA, O.C.; FURLANI, A.M.C.; TEIXEIRA, J.P.F.; FURLANI, P.R. \& GALLO, J.R. Métodos de análise química de plantas. Campinas, Instituto Agronômico de Campinas, 1983. 48p. (Boletim Técnico, 78)

BRAZ, A.J.B.P.; SILVEIRA, P.M.; KLIEMANN, H.J. \& ZIMMERMANN, F.J.P. Acumulação de nutrientes em folhas de milheto e dos capins braquiária e mombaça. Pesq. Agropec. Trop. 34:83-87, 2004.

CAMPOS, B.C.; REINERT, D.J.; NICOLODI, R. \& CASSOL, L.C. Dinâmica da agregação induzida pelo uso de plantas de inverno para cobertura do solo. R. Bras. Ci. Solo, 23:383391, 1999.

CAZETTA, D.A.; FORNASIERI FILHO, D. \& GIROTTO, F. Composição, produção de matéria seca e cobertura do solo em cultivo exclusivo e consorciado de milheto e crotalária. Acta Sci. Agron., 27:575-580, 2005.

EMPRESA BRASILEIRA DE PESQUISA AGROPECUÁRIA EMBRAPA. Manual de métodos de análise de solo. 2.ed. Rio de Janeiro, Centro Nacional de Pesquisa de Solos, 1997. 212p. (EMBRAPA-CNPS. Documentos, 1)

EMPRESA BRASILEIRA DE PESQUISA AGROPECUÁRIA EMBRAPA. Sistema brasileiro de classificação de solos. 2ed. Rio de Janeiro, Centro Nacional de Pesquisa de Solos, 2006. 306p.

GEE, G.W. \& OR, D. Particle-size analysis. In: DANE, J.H. \& TOPP, G.C., eds. Methods of soil analysis. Madison, Soil Science Society of America, 2002. Part 4. p.255-315. (SSSA Book Series, 5)

GROSSMAN, R.B. \& REINSCH, T.G. Bulk density and linear extensibility. In: DANE, J.H. \& TOPP, G.C., eds. Methods of soil analysis. Madison, Soil Science Society of America, 2002. Part 4. p.201-228. (SSSA Book Series, 5)
GUIMARÃES, G.L.; BUZETTI, S.; SILVA, E.C.; LAZARINI, E. \& SÁ, M.E. Culturas de inverno e pousio na sucessão da cultura da soja em plantio direto. Acta Sci. Agron., 25:339$344,2003$.

INSTITUTO BRASILEIRO DE GEOGRAFIA E ESTATÍSTICA - IBGE. Levantamento sistemático da produção agrícola. Available at: <http://www.ibge.gov.br/home/estatistica/indicadores/agropecuaria/lspa>. Accessed 8 Feb., 2011.

MARCELO, A.V.; CORÁ, J.E.; FERNANDES, C.; MARTINS, M.D.R. \& JORGE, R.F. Crop sequences in no-tillage system: Effects on soil fertility and soybean, maize and rice yield. R. Bras. Ci. Solo, 33:417-428, 2009.

MASCARENHAS, H.A.A.; TANAKA, R.T.; COSTA, A.A.; ROSA, F.V. \& COSTA, V.F. Efeito residual de leguminosas sobre rendimento físico e econômico da cana-planta. Campinas, Instituto Agronômico de Campinas, 1994. 15p. (Boletim Científico IAC, 32)

MORETI, D.; ALVES, M.C.; VALÉRIO FILHO, W.V. \& CARVALHO, M.P. Atributos químicos de um Latossolo Vermelho sob diferentes sistemas de preparo, adubações e plantas de cobertura. R. Bras. Ci. Solo, 31:167-175, 2007.

NIMMO, J.R. \& PERKINS, K.S. Aggregate stability and size distribution. In: DANE, J.H. \& TOPP, G.C., eds. Methods of soil analysis. Madison, Soil Science Society of America, 2002. Part 4. p.317-328. (SSSA Book Series, 5)

PERIN, A.; SANTOS, R.H.S.; URQUIAGA, S.; GUERRA, J.G.M. \& CECON, P.R. Produção de fitomassa, acúmulo de nutrientes e fixação biológica de nitrogênio por adubos verdes em cultivo isolado e consorciado. Pesq. Agropec. Bras, 39:35-40, 2004.

RAIJ, B.van; CANTARELLA, H.; QUAGGIO, J.A. \& FURLANI, A.M.C. Recomendações de adubação e calagem para o Estado de São Paulo. 2.ed. Campinas, Instituto Agronômico de Campinas, 1997. 285p. (Boletim Técnico, 100)

RAIJ, B.van; ANDRADE, J.C.; CANTARELLA, H. \& QUAGGIO, J.A. Análise química para avaliação da fertilidade de solos tropicais. Campinas, Instituto Agronômico de Campinas, 2001. 285p.

SILVA, E.C.; MURAOKA, T.; BUZETTI, S.; VELOSO, M.E.C. \& TRIVELIN, P.C.O. Aproveitamento do nitrogênio $\left({ }^{15} \mathrm{~N}\right)$ da crotalária e do milheto pelo milho sob plantio direto em Latossolo Vermelho de Cerrado. Ci. Rural, 36:739-746, 2006.

STONE, L.F. \& SILVEIRA, P.M. Efeitos do sistema de preparo e da rotação de culturas na porosidade e densidade do solo. R. Bras. Ci. Solo, 25:395-401, 2001.

STOTT, D.E.; STROO, H.F.; ELLIOTT, L.F.; PAPENDICK, R.I. \& UNGER, P.W. Wheat residue loss from fields under no-till management. Soil Sci. Soc. Am. J., 54:92-98, 1990.

SUZUKI, L.E.A.S. \& ALVES, M.C. Fitomassa de plantas de cobertura em diferentes sucessões de culturas e sistemas de cultivo. Bragantia, 65:121-127, 2006. 
SUZUKI, L.E.A.S.; ALVES, M.C.; SUZUKI, L.G.A.S. \& RODRIGUES, R.A.F. Fitomassa de plantas de cobertura sob diferentes sistemas de cultivo e sucessão de culturas em Selvíria - MS. Científica, 36:123-129, 2008.
TEDESCO, M.J.; GIANELLO, C.; BISSANI, C.A.; VOLKWEISS, S.J. \& BOHNEN, H. Análise de solos, plantas e outros materiais. Porto Alegre, Universidade Federal do Rio Grande do Sul, 1995. 174p. 